\title{
Effect of iron application on iron nutrition of aerobic rice grown in different soils
}

\author{
B.L. Meena ${ }^{1 *}$, R.K. Rattan ${ }^{2}$, S.P.Datta and M.C. Meena ${ }^{2}$ \\ 'Project Coordinating Unit, ICAR-Central Soil Salinity Research Institute, Karnal-132 001, India \\ ${ }^{2}$ Division of Soil Science and Agricultural Chemistry, ICAR-Indian Agricultural Research Institute, New Delhi-110 012, India \\ *Corresponding Author E-mail: blmeena2008@gmail.com
}

\section{Publication Info}

Paper received:

26 April 2016

Revised received:

10 June 2016

Accepted:

05 August 2016

Abstract

Enhancing the content of $\mathrm{Fe}$ in edible portion of rice for improving human health is a global challenge. A greenhouse experiment was conducted to evaluate the relative effectiveness of soil, foliar and seed treatment of $\mathrm{Fe}$ in alleviating Fe-deficiency using two rice cultivars (IR-64 and Pusa Sugandh-3) grown on alkaline, calcareous, acid and lime-treated acid soils. Results showed that on an average, soil application of $\mathrm{Fe}$ improved the available $\mathrm{Fe}$ status of soil $\left(8.14 \mathrm{mg} \mathrm{kg}^{-1}\right)$ over control $\left(6.79 \mathrm{mg} \mathrm{kg}^{-1}\right)$. The foliar application of $\mathrm{Fe}\left(3 \% \mathrm{FeSO}_{4} .7 \mathrm{H}_{2} \mathrm{O}\right.$ solution, thrice 40,60 and 75 days after sowing of rice) was more effective and economical in enhancing the yield $(9.42 \%)$ as well as increasing Fe content (3.48\%) of milled rice as compared to soil application (67 $\mathrm{mg} \mathrm{FeSO}{ }_{4} \cdot 7 \mathrm{H}_{2} \mathrm{O} \mathrm{kg}^{-1}$ ). Among the soils, acid soil (without lime) produced highest yield (27.4 g pot $\left.{ }^{1}\right)$ of aerobic rice followed by alkaline $\left(21.2 \mathrm{~g} \mathrm{pot}^{-1}\right)$, calcareous $\left(20.0 \mathrm{~g} \mathrm{pot}^{-1}\right)$ and lime-treated acid soils (17.7 $\left.\mathrm{g} \mathrm{pot}^{-1}\right)$. Pusa Sugandh-3 (23.4 $\left.\mathrm{g} \mathrm{pot}^{-1}\right)$ performed better under aerobic condition compared to IR-64 (19.7 $\mathrm{g} \mathrm{pot}^{-1}$ ). Ferrous-iron content in rice plants proved to be a better index of Fe nutrition status compared to total plant $\mathrm{Fe}$ and chemically extractable soil $\mathrm{Fe}$. The $\mathrm{Fe}^{2+}$ content of $\geq 42 \mathrm{mg} \mathrm{kg}^{-1}$ in plants (on dry weight basis) appeared to be an adequate level at 45 days after sowing for rice grown under upland aerobic condition.

Key words

Aerobic rice, Biofortification, Fe-deficiency, Foliar application, Seed treatment

\section{Introduction}

Owing to increasing water scarcity, "Aerobic rice" is a new system to save water in rice, where rice grows in nonpuddled and unsaturated (aerobic) soil without ponded water, just like upland crops. Bouman et al. (2005) also reported that irrigation requirement of aerobically grown rice is reduced by $63-65$ and $15-68 \%$ in dry and wet seasons, respectively as compared to that required for flooded rice. However, rice is a poor source of many essential minerals, especially of iron (Fe) for human nutrition (Chandel et al., 2010). Low dietary intake of $\mathrm{Fe}$ appears to be a major reason for widespread prevalence of Fe-deficiency in human population (WHO, 2016). Growing rice on potentially Fe-deficient soils, as well as, not following good agronomic practices further reduces Fe concentration in grain (Cakmak, 2010).
Iron deficiency in rice mainly occurs under upland conditions, particularly in alkaline and calcareous soils (Sasaki et al., 2010). Some times severe chlorosis in rice due to Fe-deficiency has led to complete failure of rice crop (Katyal and Sharma, 1980). In most of the studies, foliar application of $\mathrm{Fe}$ has an edge over soil application (Datta et al., 2003). Iron is easily translocated acropetally and even retranslocated basipetally after foliar application as long as $\mathrm{Fe}$ does not get immobilized. But $\mathrm{Fe}^{2+}$ salts rapidly oxidize upon exposure to ambient air under field conditions (Fernandez and Ebert, 2005). Also, the efficacy of foliar spray varies with species and cultivars (Datta et al., 2003). Seeds are capable of absorbing not only water but also organic and inorganic substances present in the medium, during germination. However, there are contradictory reports in a limited number of studies regarding the effectiveness of 
seed treatment with Fe in controlling chlorosis in case of soybean and other crops (Goos and Johnson, 2001). The available information pertaining to ways and means for ameliorating Fe-deficiency in rice has mostly been confined to transplanted rice grown under anaerobic lowland condition. Such information is yet to be generated for direct seeded aerobically-grown rice.

A limited number of studies indicate that prediction of Fe-deficiency based on total Fe concentration in plant tissues has not been successful, because chlorotic plants reportedly have as much or higher $\mathrm{Fe}$ than the green ones; the $\mathrm{Fe}^{2+}$ concentration in leaves is more useful than total $\mathrm{Fe}$ concentration as an indicator of its nutritional status in plant (Takkar and Kaur, 1984). Limited information is available on the adequate level of $\mathrm{Fe}^{2+}$ in rice plants of different cultivars under field conditions which can be used for monitoring purpose. Also, information on the relative efficacy of seed treatment, soil and foliar application of $\mathrm{Fe}$ in maintaining $\mathrm{Fe}^{2+}$ concentration and enriching the grain with $\mathrm{Fe}$ content in plants is meagre. Such information is potentially useful in ameliorating Fe-deficiency and increasing Fe content of grain under aerobic rice.

In view of the above, the present investigation was carried out to study the relative efficacy of methods of iron application on alleviating Fe deficiency and enriching rice grain with $\mathrm{Fe}$ in aerobically grown rice.

\section{Materials and Methods}

Collection and analysis of soil samples : Three bulk surface $(0-15 \mathrm{~cm})$ soil samples were collected from IARI farm, New Delhi (alkaline), Birauli KVK farm, Bihar (calcareous) and Ranchi, Jharkhand (acid). The collected soil samples were air-dried, ground and sieved to pass through $2 \mathrm{~mm}$ sieve. Lime was added to acid soil of Ranchi@6.52 g pure $\mathrm{CaCO}_{3}$ per $5 \mathrm{~kg}$ soil (pot) and incubated for one month at field capacity (moisture content) (Shoemaker et al., 1961) in ambient temperature. This dose of lime application is equivalent to 3.0 tha $^{-1}$ at field level, which is a common rate of lime application of the region (Sarkar, 2015). The $\mathrm{pH}$ of lime treated soil was raised to 7.52. These processed soil samples were used for greenhouse experiment, as well as subsequent chemical analysis using standard procedures (Jackson, 1973). Selected properties of experimental soils are given in Table 1. Soil samples were extracted with DTPA (Lindsay and Norvell, 1978) and Fe content in the extract was determined by Flame Atomic Absorption Spectrophotometer. For determination of exchangeable Fe, soil samples were extracted with $1 \mathrm{~N}$ ammonium acetate (Olson and Carlson, 1950) immediately after collection soil samples.

Greenhouse experiment : A pot experiment was conducted during 2012 in a greenhouse on four soils viz. alkaline, calcareous, acid and lime-treated acid soils at the Division of Soil Science and Agricultural Chemistry, Indian Agricultural Research Institute, New Delhi, India. Five kilogram of soil was filled into blue plastic pots (height $20 \mathrm{~cm}$ and inside diameter $19 \mathrm{~cm}$ ). A uniform basal dose of 53.6, 11.7 and 14.9 $\mathrm{mg} \mathrm{kg}^{-1}$ of $\mathrm{N}$ [1/3 each at the time of sowing, 30 and 60 days after sowing (DAS) of rice], $\mathrm{P}$ and $\mathrm{K}$ was added to soil in the form of urea, ammonium dihydrogen orthophosphate and muriate of potash, respectively. The NPK fertilizers were added in solution form and thoroughly mixed with soil. Two rice (Oryza sativa L.) cultivars were used viz., IR-64 (inefficient to Fe-deficiency) and Pusa Sugandh-3 (efficient to Fe-deficiency). Efficient cultivar could extract more amount of Fe from deficient soil than inefficient cultivar. Four levels of Fe were applied as control, soil application of $67 \mathrm{mg} \mathrm{FeSO}_{4} .7 \mathrm{H}_{2} \mathrm{O} \mathrm{kg}^{-1}$ soil at the time of sowing, three foliar sprays (at 40, 60 and $75 \mathrm{DAS}$ ) of $3 \% \mathrm{FeSO}_{4} .7 \mathrm{H}_{2} \mathrm{O}$ solution, and $0.05 M$ Fe-EDTA used as seed treatment. Foliar sprays were performed three times with the help of a mini air-jet sprayer and $20 \mathrm{ml}$ of Fe-containing solution (3\%) was sprayed per pot each time. For seed treatment, two hundred viable seeds of each cultivar were taken in a $50 \mathrm{ml}$ beaker and $20 \mathrm{ml}$ of $0.05 M \mathrm{Fe}-E D T A$ solution was added to only seed

Table 1 : Selected physico-chemical properties of experimental soils

\begin{tabular}{|c|c|c|c|c|}
\hline Parameter & Alkaline soil & Calcareous soil & Acid soil & Lime-treated acid soil \\
\hline Location & New Delhi & Birauli & Ranchi & Ranchi \\
\hline Sub-group as per Soil Taxonomy & Typic Haplustept & Typic Calciorthents & Typic Paleustalfs & Typic Paleustalfs \\
\hline $\mathrm{pH}_{1: 2}$ & 7.80 & 8.00 & 5.80 & 7.52 \\
\hline $\mathrm{EC}_{1: 2}\left(\mathrm{dS} \mathrm{m}^{-1}\right)$ & 0.66 & 0.69 & 0.27 & 0.30 \\
\hline \multicolumn{5}{|l|}{ Mechanical composition } \\
\hline Clay $(\%)$ & 27.4 & 21.4 & 33.4 & 33.4 \\
\hline Silt (\%) & 27.0 & 57.0 & 20.0 & 20.0 \\
\hline Sand $(\%)$ & 45.6 & 21.6 & 46.6 & 46.6 \\
\hline Texture class & Sandy clay loam & Silt loam & Sandy clay loam & Sandy clay loam \\
\hline Organic carbon $\left(\mathrm{g} \mathrm{kg}^{-1}\right)$ & 4.30 & 5.10 & 6.20 & 6.20 \\
\hline DTPA- Fe $\left(\mathrm{mg} \mathrm{kg}^{-1}\right)$ & 4.01 & 3.49 & 11.0 & 8.02 \\
\hline
\end{tabular}


treatment combination. The beakers of both the cultivars were kept for $12 \mathrm{hrs}$ at room temperature of about $25^{\circ} \mathrm{C}$. Sixteen soaked seeds were taken out from beaker with help of stainless steel forecep and sown in pots at $2.5 \mathrm{~cm}$ depth in the holes of soil. Thus, all the thirty-two ( 4 soils $\mathrm{x} 2$ cultivars $\mathrm{x} 4$ levels of $\mathrm{Fe}$ ), treatment combinations were replicated thrice in a completely randomized design. Soil in each pot was then irrigated to field capacity with water. Sixteen rice seeds were sown and after two weeks of sowing, a uniform plant population (eight plants pot ${ }^{-1}$ ) was maintained in each pot. Throughout the period of experimentation, crop was irrigated at an interval of 2-3 days depending upon temperature so as to maintain soil moisture approximately between field capacity and water saturation. Ferrous-iron $\left(\mathrm{Fe}^{2+}\right)$ concentration in fresh plant samples was determined at 45 days after sowing. The crops were harvested at maturity; straw and grain yields were recorded; representative samples were kept for analysis.

Plant analysis : $\mathrm{Fe}^{2+}$ concentration in fresh plant samples was determined by $o$-ophenanthroline method as developed by Katyal and Sharma (1980). Plant samples were digested in diacid $\mathrm{HNO}_{3}: \mathrm{HClO}_{4}(9: 4)$ mixture (Jackson, 1973) for estimation of total Fe content.

\section{Results and Discussion}

Extractable Fe in soil after harvest of rice : The DTPA extractable $\mathrm{Fe}$ of soils was influenced by $\mathrm{Fe}$ application methods after harvesting of rice crop (Table 2). On an average, mean DTPA extractable Fe content was 4.31, 3.88, 12.35 and $8.46 \mathrm{mg} \mathrm{kg}^{-1}$ in alkaline, calcareous, acid and limetreated acid soil, respectively. As expected, mean DTPA extractable Fe was 11.1, 218 and 118\% higher in alkaline, acid and lime-treated acid soils as compared to calcareous soil. The DTPA extractable Fe in soil significantly increased due to soil application of $\mathrm{Fe}$ over control; while, foliar application of Fe did not bring any change. Because most of applied $\mathrm{Fe}$ is retained on the foliage of rice and amount of $\mathrm{Fe}$ applied through foliar spray is much less as compared to soil application. Pal et al. (2008) revealed that application of Fe (a) $60.95 \mathrm{~kg} \mathrm{ha}^{-1}$ increased DTPA extractable Fe content in soil, while foliar spray at $3 \% \mathrm{FeSO}_{4}$ at par with control. The seed treatment with $0.05 \mathrm{M}$ Fe-EDTA maintained DTPA extractable as $7.11 \mathrm{mg} \mathrm{kg}^{-1}$, which was significantly higher than control. It is difficult to explain the reason for such an improvement due to seed treatment. Such marginal increase in DTPA extractable Fe may probably be attributed to addition of EDTA at the time of sowing of seeds, as EDTA being an effective chelating agent is capable of enhancing the solubility of $\mathrm{Fe}$ in the soils. The interactive effect of soil type and applied $\mathrm{Fe}$ was significant. Among the soils, highest DTPA extractable Fe was obtained in acid soil as compared to alkaline, calcareous and lime-treated soils under soil $\mathrm{Fe}$ application and seed treatment. This might be attributed to variation in initial soil properties and these results are in the agreement with previous studies of Sidhu and Sharma (2010) and Zeng et al. (2016). Soil $\mathrm{pH}$ predominantly regulates the solubility and availability of Fe. Solubility and consequential bioavailability of Fe were decreases above $\mathrm{pH} 6.0$ (Datta and Meena, 2015). Generally calcareousness of soil induces Fe deficiency.

The mean value of $\mathrm{NH}_{4} \mathrm{OAc}$ extractable $\mathrm{Fe}$ was found to be $2.18,2.02,6.20$ and $4.29 \mathrm{mg} \mathrm{kg}^{-1}$ in alkaline, calcareous, acid and lime-treated acid soils, respectively (Table 2). The content of $\mathrm{NH}_{4} \mathrm{OAc}$ extractable $\mathrm{Fe}$ was 4.12 and $3.59 \mathrm{mg} \mathrm{kg}^{-1}$ under soil application of $\mathrm{Fe}$ and seed treatment, respectively, which were significantly higher than control. Like DTPA, $\mathrm{NH}_{4} \mathrm{OAc}-\mathrm{Fe}$ varied similarly under soil application of Fe and seed treatment. However, $\mathrm{NH}_{4} \mathrm{OAc}$ reagent extracted proportionately lower amounts of $\mathrm{Fe}$ under various treatments as compared to DTPA. The interactive effect of soil type and applied Fe was significant. Higher extractability of DTPA than $\mathrm{NH}_{4} \mathrm{OAc}$ is attributed to the ability of DTPA to form soluble stable Fe-chelate.

Yield and plant iron content : On an average, significantly higher grain yield was obtained with cultivar Pusa Sugandh-3 (19 $\left.\mathrm{g} \mathrm{pot}^{-1}\right)$ as compared to IR-64 (15 $\left.\mathrm{g} \mathrm{pot}^{-1}\right)$. Differential behaviour of rice cultivars in terms of yield was related to inherent characteristics of cultivars (Zou et al., 2007) to perform under water stress condition as imposed under

Table 2 : DTPA-and ammonium acetate-extractable Fe $\left(\mathrm{mg} \mathrm{kg}^{-1}\right)$ in different soils as influenced by the methods of iron application at harvest of rice

\begin{tabular}{|c|c|c|c|c|c|}
\hline \multirow[t]{2}{*}{ Methods of Fe application } & \multicolumn{4}{|c|}{ Soil } & \multirow[b]{2}{*}{ Mean } \\
\hline & Alkaline & Calcareous & Acid & Lime-treated acid & \\
\hline Control & $4.11^{\#}(2.09)^{\mathrm{s}}$ & $3.58(1.91)$ & $11.4(5.74)$ & $8.09(4.10)$ & $6.79(3.46)$ \\
\hline $67 \mathrm{mg} \mathrm{FeSO}_{4} \mathrm{~kg}^{-1}$ & $4.66(2.35)$ & $4.06(2.12)$ & $14.3(7.22)$ & $9.53(4.80)$ & $8.14(4.12)$ \\
\hline Three foliar sprays $\left(3 \% \mathrm{FeSO}_{4}\right)$ & $4.20(2.12)$ & $3.90(2.02)$ & $11.6(5.84)$ & $8.09(4.10)$ & $6.96(3.52)$ \\
\hline $0.05 M \mathrm{Fe}-\mathrm{EDTA}($ Seed treatment) & $4.25(2.14)$ & $4.00(2.05)$ & $12.0(6.02)$ & $8.14(4.15)$ & $7.11(3.59)$ \\
\hline Mean & $4.31(2.18)$ & $3.88(2.02)$ & $12.3(6.20)$ & $8.46(4.29)$ & \\
\hline $\operatorname{LSD}(P=0.05)$ & $\mathrm{S}=0.23(0.11)$ & $\mathrm{Fe}=0.23(0.11)$ & $\mathrm{S} \times \mathrm{Fe}=0.47(0.22)$ & & \\
\hline
\end{tabular}

"DTPA-extractable Fe; Ammonium extractable-Fe 
aerobic rice cultivation. Highest grain yield was obtained in acid soil (21.7 $\left.\mathrm{g} \mathrm{pot}^{-1}\right)$ followed by alkaline (17.6 $\left.\mathrm{g} \mathrm{pot}^{-1}\right)$, calcareous (17.3 $\left.\mathrm{g} \mathrm{pot}^{-1}\right)$ and lime-treated acid soil (11.6 g pot ${ }^{1}$ ) (Fig. 1). Grain yield was reduced up to $45 \%$, when acid soil was treated with lime. Barman et al. (2014) reported that liming of acid soil induced deficiency of boron along with other nutrients which had detrimental effect on yield of sunflower. The effect of Fe application and soil type and their interaction was significant on grain yield of rice (Fig. 1). On an average, three foliar sprays of $3 \% \mathrm{FeSO}_{4} \cdot 7 \mathrm{H}_{2} \mathrm{O}$ produced highest grain yield to the tune of $18.9 \mathrm{~g} \mathrm{pot}^{-1^{-1}}$ followed by soil application (17.5 $\left.\mathrm{g} \mathrm{pot}^{-1}\right)$ and seed treatment (16.1 $\left.\mathrm{g} \mathrm{pot}^{-1}\right)$, whereas lowest grain yield was recorded under control (15.7 $\left.\mathrm{g} \mathrm{pot}^{-1}\right)$. The mean response of rice in terms of grain yield was 11.9, 20.5 and 3.0\% with Fe application by soil, foliar and seed treatments, respectively over control. However, seed treatment $\left(16.1 \mathrm{~g} \mathrm{pot}^{-1}\right)$ was statistically at par with control. In case of straw, the highest yield (24.4 $\left.\mathrm{g} \mathrm{pot}^{-1}\right)$ was obtained with three foliar sprays, followed by soil application $(22.3 \mathrm{~g}$ $\left.\operatorname{pot}^{-1}\right)$, seed treatment $\left(20.1 \mathrm{~g} \mathrm{pot}^{-1}\right)$ and control (19.5 $\left.\mathrm{g} \mathrm{pot}^{-1}\right)$.

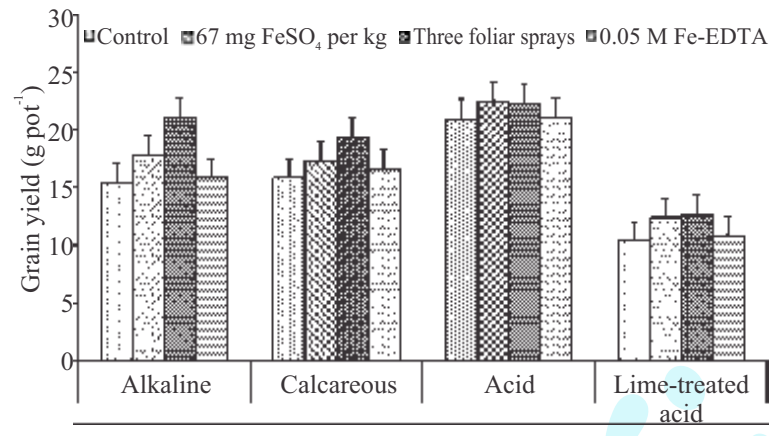

Fig. 1 : Interactive effect of soils types and methods of applied Fe on grain yield (g pot-1) of rice. Error bars represent the least significant difference (LSD, $\mathrm{P} \leq 0.05)$ between the two treatments

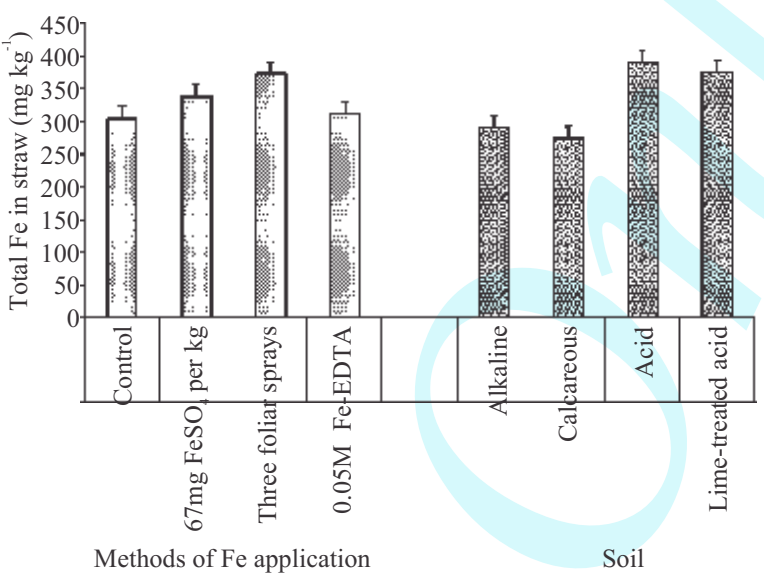

Fig. 2 : Total Fe content $\left(\mathrm{mg} \mathrm{kg}^{-1}\right)$ in rice straw under different methods of $\mathrm{Fe}$ application and soils. Error bars represent the least significant difference $(\mathrm{LSD}, \mathrm{P} \leq 0.05)$ between the two treatments
Acid soil produced highest straw yield (27.4 $\left.\mathrm{g} \mathrm{pot}^{-1}\right)$, followed by alkaline (21.2 $\left.\mathrm{g} \mathrm{pot}^{-1}\right)$, calcareous (20.0 $\left.\mathrm{g} \mathrm{pot}^{-1}\right)$ and lime-treated acid soil $\left(17.7 \mathrm{~g} \mathrm{pot}^{-1}\right)$. It appears that seed treatment was not much effective in increasing the rice yield due to lower rate of supplementation of Fe through this method. Foliar application of Fe was more effective in enhancing the grain yield of rice over control than that of soil application. Superiority of foliar application of Fe over soil application has been reported by many researchers (Datta et al., 2003; Pal et al., 2008; Zhang et al., 2009; Gomez-Galera et al., 2010). Iron is easily translocated acropetally and retranslocated basipetally after foliar application as long as Fe does not get immobilized. But Fe (II) salts rapidly oxidize upon exposure to ambient air after soil application (Fernandez and Ebert, 2005). Relative ineffectiveness of soil application of Fe through inorganic source is attributed to quick conversion of $\mathrm{Fe}$ from $\mathrm{Fe}^{2+}$ to $\mathrm{Fe}^{3+}$ under field condition with high $\mathrm{pH}$ rendering its unavailability to plants (Sarkar et al., 2008). Interactive effect of soil type and applied Fe on grain yield was statistically significant, indicating that efficiency of applied $\mathrm{Fe}$ on yield varied with soil types. In terms of yield, the response of applied $\mathrm{Fe}$ on different soil types decreased with increase in the level and solubility of native $\mathrm{Fe}$ in acid soil as compared to higher $\mathrm{pH}$ soils. Ai-Qing et al. (2011) also reported that Fe supply increased plant dry weight in wheat as compared to Fe deficient treatment.

On an average, straw Fe content of Pusa Sugandh-3 was significantly higher (358 $\mathrm{mg} \mathrm{kg}^{-1}$ ) as compared to IR-64 (306 mg kg ${ }^{-1}$ ). Differences in Fe content in straw of theses cultivars content exhibited by crop cultivars may be genetically controlled (Chandel et al., 2010). Pusa Sughandh-3 is probably better extractor of soil Fe from the reserve pools. The lowest total $\mathrm{Fe}$ in straw of plant grown on calcareous soil (Fig. 2) is due to its inherently poor Fe supplying capacity related to low DTPA-extractable Fe and high $\mathrm{CaCO}_{3}$ content (Datta and Meena, 2015). Mean variation in DTPA-extractable Fe in soil was also reflected on total Fe content of plant (Golia et al., 2009). Highest Fe content in straw was observed under foliar spray of Fe, followed by soil application; whereas, seed treatment was ineffective in enhancing the straw Fe content.

The mean $\mathrm{Fe}^{2+}$ content in fresh rice leaves of IR-64 and Pusa Sugandh-3 at 45 DAS was 36.4 and $46.5 \mathrm{mg} \mathrm{kg}^{-1}$ (d. wt.), respectively. Such variability in $\mathrm{Fe}^{2+}$ content between these two cultivars is attributed to the inherent genetic differences in ability of the cultivars to mine Fe from the soil pool (Pal et al., 2008). On an average, $\mathrm{Fe}^{2+}$ content in shoot of rice plants was highest in acid soil, followed by alkaline, calcareous and lime-treated acid soils (Table 3). Soil and one foliar application of $\mathrm{Fe}$ were equally effective in maintaining the $\mathrm{Fe}^{2+}$ content in plants. Seed treatment significantly increased the $\mathrm{Fe}^{2+}$ content in plants over control. On dry 
Table 3: Effect of methods of Fe application on ferrous-Fe content ( $\mathrm{mg} \mathrm{kg}^{-1}$, d. wt.) of rice at 45 days after sowing in different soils

\begin{tabular}{|c|c|c|c|c|c|}
\hline \multirow[t]{2}{*}{ Methods of Fe application } & \multicolumn{4}{|c|}{ Soil (S) } & \multirow[b]{2}{*}{ Mean } \\
\hline & Alkaline & Calcareous & Acid & Lime-treated acid & \\
\hline Control & 38.6 & 36.5 & 43.0 & 37.2 & 38.8 \\
\hline $67 \mathrm{mg} \mathrm{FeSO}_{4} \mathrm{~kg}^{-1}$ & 45.1 & 41.1 & 47.2 & 39.7 & 43.3 \\
\hline One foliar spray $\left(3 \% \mathrm{FeSO}_{4}\right)$ & 43.7 & 42.0 & 45.5 & 39.9 & 42.8 \\
\hline $0.05 M \mathrm{Fe}-\mathrm{EDTA}($ Seed treatment) & 41.9 & 38.9 & 43.8 & 39.1 & 40.9 \\
\hline Mean & 42.4 & 39.7 & 44.9 & 38.9 & \\
\hline $\operatorname{LSD}(P=0.05)$ & $\mathrm{S}=1.3$ & $\mathrm{Fe}=1.3$ & $\mathrm{~S} \times \mathrm{Fe}=2.6$ & & \\
\hline
\end{tabular}

Table 4 : Simple correlation coefficient (r) among different soil and plant parameters

\begin{tabular}{|c|c|c|c|c|c|c|}
\hline \multirow[t]{2}{*}{ Soil and plant parameters } & \multicolumn{5}{|c|}{ Correlation coefficient (r) } & \multirow[b]{2}{*}{ Straw yield } \\
\hline & Total plant-Fe & Plant-Fe ${ }^{2+}$ at & Milled rice-Fe & Husk-Fe & Grainyield & \\
\hline & at harvest & $45 \mathrm{DAS}$ & & & & \\
\hline DTPA-Fe at harvest ${ }^{\mathrm{a}}$ & $0.78 * *$ & 0.30 & $0.48^{*}$ & $0.65 * *$ & 0.35 & $0.64 * *$ \\
\hline $\mathrm{NH}_{4} \mathrm{OAc}-\mathrm{Fe}$ at harvest ${ }^{\mathrm{a}}$ & $0.78 * *$ & 0.30 & $0.48^{*}$ & $0.65 * *$ & 0.35 & $0.64 * *$ \\
\hline Plant-Fe ${ }^{2+}$ at $45 \mathrm{DAS}^{\mathrm{b}}$ & $0.55^{* *}$ & - & $0.88 * *$ & $0.54 * *$ & $0.77 * *$ & $0.76^{* *}$ \\
\hline Total plant-Fe at harvest ${ }^{\mathrm{b}}$ & - & $0.55 * *$ & $0.54 * *$ & $0.44 *$ & 0.34 & $0.56^{* *}$ \\
\hline
\end{tabular}

${ }^{\mathrm{a}}$ Based on all the treatment combinations except foliar spray and seed treatment ( 16 observations); ${ }^{\mathrm{b}}$ Based on all the treatment combinations $(32$ observations); * and ** indicate that values of ' $r$ ' are significant at 5 and $1 \%$ probability levels, respectively

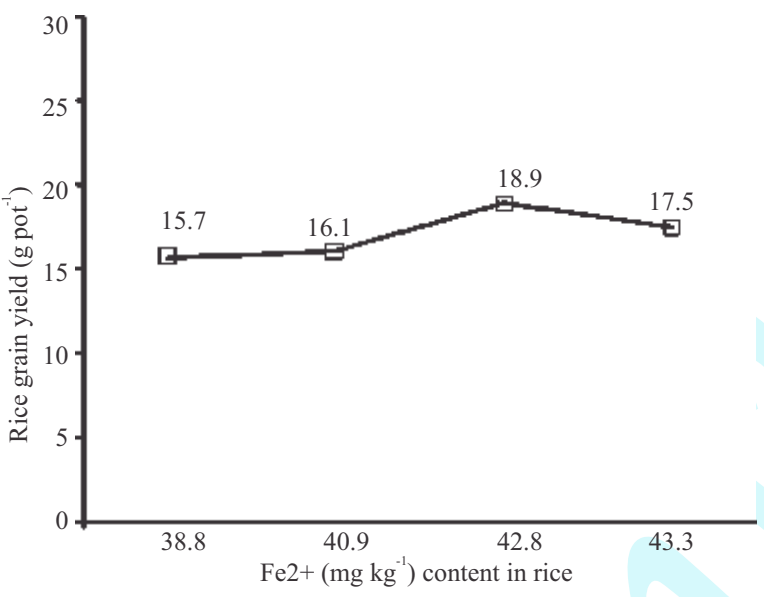

Fig. 3 : Relationship between mean value of Fe2+ content in plants and rice grain yield

weight basis, Katyal and Sharma (1980) reported 50-55 mg $\mathrm{Fe}^{2+} \mathrm{kg}^{-1}$ of green rice plants at 30-40 days after transplanting as compared to $27-30 \mathrm{mg} \mathrm{Fe}^{2+} \mathrm{kg}^{-1}$ of chlorotic rice plants collected from the farmer's field. Relationship of $\mathrm{Fe}^{2+}$ content in plant and grain yield is depicted in Fig. 3. Considering this relationship as well as appearance of plants, the $\mathrm{Fe}^{2+} \geq 42 \mathrm{mg}$ $\mathrm{kg}^{-1}$ plants (dry weight basis) at 45 DAS could be considered as a guide value for adequacy $\mathrm{Fe}^{2+}$ in rice plant. Simple computation shows that three foliar sprays required much lower amount of $\mathrm{FeSO}_{4} \cdot 7 \mathrm{H}_{2} \mathrm{O}$ as compared to soil

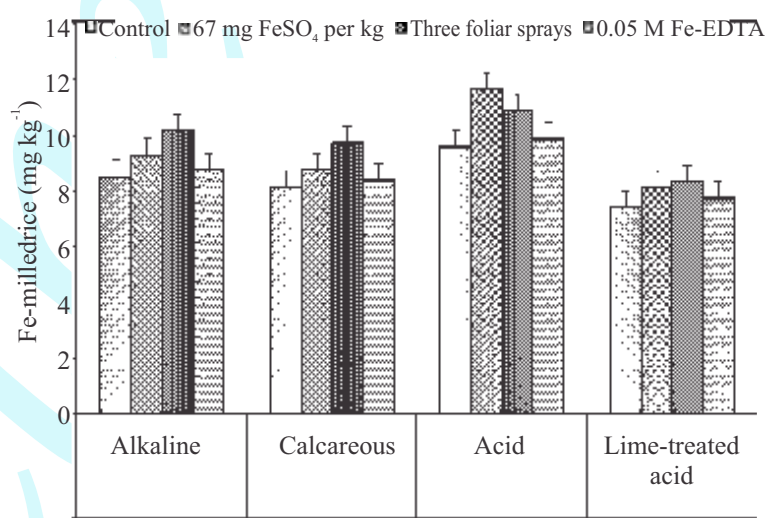

Fig. 4 : Interactive effect of methods of Fe application and soils on totalFe content $\left(\mathrm{mg} \mathrm{kg}^{-1}\right)$ in milled rice. Error bars represent the least significant difference (LSD, $\mathrm{P} \leq 0.05)$ between the two treatments

application; in addition to significantly higher yield obtained with application of $\mathrm{Fe}$ to foliage. Hence, economics also favours application of Fe through foliar spray against soil application.

On an average, $\mathrm{Fe}$ content in grain was 8.16 and 10.0 $\mathrm{mg} \mathrm{kg}^{-1}$ in IR-64 and Pusa Sugandh-3, respectively. Such variability is attributed to the inherent genetic characteristics of rice cultivars. Chandel et al. (2010) also reported that genotype differences among the rice cultivars were the most 


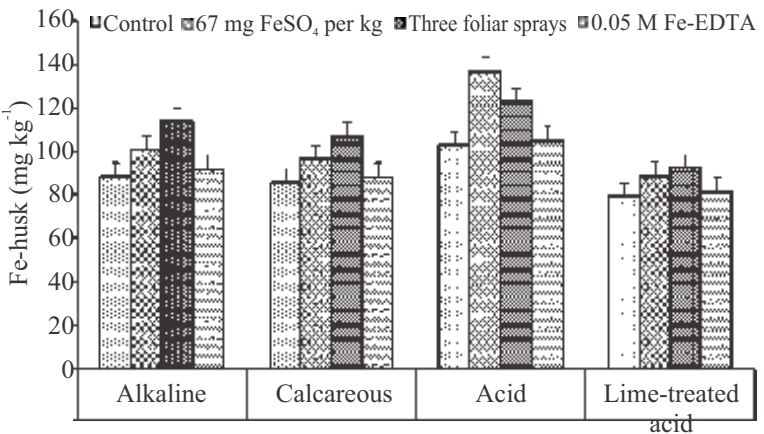

Fig. 5 : Effect of methods of Fe application on total-Fe content in husk $\left(\mathrm{mg} \mathrm{kg}^{-1}\right)$ of rice grown on different soils. Error bars represent the least significant difference (LSD, $\mathrm{P} \leq 0.05$ ) between the two treatments

significant factor affecting grain-Fe contents in a large number of genotypes. The average grain-Fe content of both rice cultivars grown on acid soil $\left(10.5 \mathrm{mg} \mathrm{kg}^{-1}\right)$ was found to be higher than average grain-Fe content of the same set of cultivars grown on alkaline, calcareous and lime-treated acid soil i.e. 9.20, 8.75 and $7.91 \mathrm{mg} \mathrm{kg}^{-1}$, respectively (Fig. 4). Such variation is attributed to the variation in the properties of experimental soils. Similar were the findings of Chandel et al. (2010) who reported that Fe content of rice genotypes significantly varied with soil properties such as $\mathrm{pH}$, organic matter and Fe status of soil. The grain-Fe content of rice was significantly reduced after application of lime to acid soil of $\mathrm{pH}$ 5.8. The Fe content of grain was increased by $12.5,16.4$ and $3.10 \%$ due to soil and foliar application and seed treatment of Fe over control; seed treatment was inefficient in enhancing the grain-Fe content over control.

On an average, the $\mathrm{Fe}$ content in husk varied significantly from $97 \mathrm{mg} \mathrm{kg}^{-1}$ in IR-64 to $101 \mathrm{mg} \mathrm{kg}^{-1}$ in Pusa Sugandh-3, which is attributed to the inherent characteristics of cultivars. The Fe content in husk of rice cultivars grown on calcareous, acid and lime-treated acid soil was 99.1, 94.7, 117 and $85.6 \mathrm{mg} \mathrm{kg}^{-1}$, respectively (Fig. 5). In general, the Fe content in husk of cultivars was significantly higher in acid soil as compared to the rest of the soils studied. The Fe content in husk was reduced by $27.1 \%$ with lime amendment. The highest $\mathrm{Fe}$ content in husk of rice $\left(109 \mathrm{mg} \mathrm{kg}^{-1}\right)$ was obtained with three foliar sprays followed by soil application (106 $\left.\mathrm{mg} \mathrm{kg}^{-1}\right)$, seed treatment $\left(92.0 \mathrm{mg} \mathrm{kg}^{-1}\right)$ as compared to control (89.4 $\left.\mathrm{mg} \mathrm{kg}^{-1}\right)$.

The values of correlation coefficient of both DTPA and $\mathrm{NH}_{4} \mathrm{OAc}$ extractable $\mathrm{Fe}$ in different soils at harvest showed positive relationship with total $\mathrm{Fe}$ content in plant and husk, as well as straw yield of rice. However, $\mathrm{Fe}^{2+}$ content in plant, milled rice-Fe (grain) and grain yield of rice did not show any relationship with extractable Fe in soil (Table 4).
Further, perusal of the correlation coefficient values revealed that $\mathrm{Fe}^{2+}$ content in plant had more consistent association with yield and $\mathrm{Fe}$ content in milled rice and husk as compared to total $\mathrm{Fe}$ content in plant. These results indicate that $\mathrm{Fe}^{2+}$ content is better indicator of iron nutrition status of rice plants than that of total plant Fe content. Hence, we confirm the findings of Pal et al. (2008). Chlorotic plants reportedly have as much or higher total iron than green ones; due to accumulation of $\mathrm{Fe}$ in deficient plants. These results clearly underline the importance of $\mathrm{Fe}^{2+}$ in plants as compared to total plant-Fe, as dictator of crop productivity.

Foliar application of $\mathrm{Fe}$ is an effective way of alleviating its deficiency in aerobically grown rice. Ferrous iron $\left(\mathrm{Fe}^{2+}\right) \geq 42 \mathrm{mg} \mathrm{kg}^{-1}$ (d.wt.) at 45 DAS can be used as a guide value for assessing Fe deficiency in rice. Agronomic measures are not very effective in enhancing Fe density in rice grain.

\section{Acknowledgments}

The authors are grateful to the Head, Division of Soil Science and Agricultural Chemistry, ICAR-IARI, New Delhi for providing the required research facilities and first author also grateful to the Director, ICAR-CIARI, Port Blair for providing study leave for $\mathrm{Ph} . \mathrm{D}$. programme.

\section{References}

Ai-Qing, Z., Q.L. Bao, X.H. Tian, X.C. Lu and J.G. William: Combined effect of iron and zinc on micronutrient levels in wheat (Triticum aestivum L.). J. Environ. Biol., 32, 235-239 (2011).

Barman, M., L.M. Shukla, S.P. Datta and R.K Rattan: Effect of applied lime and boron on the availability of nutrients in an acid soil. $J$. Plant Nutr., 37, 357-373 (2014).

Bouman, B.A.M., S. Peng, A.R. Castaneda and R.M. Visperas: Yield and water use of irrigated tropical aerobic rice systems. Agric. Water Manage., 74, 87-105 (2005).

Cakmak, I.: Biofortification of cereals with zinc and iron through fertilization strategy. In: $19^{\text {th }}$ World Congress of Soil Science, Soil Solution for a Changing World.1-6 August 2010, Brisbane, Australia (2010).

Chandel, G.S., S. Banerjee, R. Meena, D.J. Sharma and S.B. Verulkar: Effects of different nitrogen fertilizer levels and native soil properties on rice grain Fe, $\mathrm{Zn}$ and protein contents. Rice Sci., 17, 213-227(2010).

Datta, S.P. and M.C. Meena: Micronutrients in soils and their management. In: Soil Science; An Introduction (Eds.: R.K. Rattan, J.C. Katyal, B.S. Dwivedi, A.K. Sarkar, T. Bhattacharyya, J.C. Tarafdar and S.S. Kukal). Indian Society of Soil Science, New Delhi, 623-648(2015).

Datta, S.P., N. Saharan and R.K. Rattan: Micronutrient fertilizers, sources and methods of application. In: Integrated Micronutrient Management for Sustainable Agriculture (Eds.: D.K. Das and D. Saha). BCKV, West Bengal, India, pp.71-89 (2003).

Fernandez, V. and G. Ebert: Foliar iron fertilization: A critical review. $J$. Plant Nutr., 28, 2113-2124(2005). 
Golia, E.E., A. Dimirkou and I.K. Mitsios: Heavy-metal concentration in tobacco leaves in relation to their available soil fractions. Comm. Soil Sci. Plant Analy., 40, 106-120 (2009).

Gomez-Galera, S., E. Rojas, D. Sudhakar, C. Zhu, A.M. Pelacho, T. Capell and P. Christou: Critical evaluation of strategies for mineral fortification of staple food crops. Transgic. Res., 19, 165-180 (2010).

Goos, R.J. and B.E. Johnson: Seed treatment, seeding rate, and cultivar effects on iron deficiency chlorosis of soybean. J. Plant Nutr., 24, 1255-1268 (2001).

Jackson, M.L.: Soil Chemical Analysis. Prentice Hall of India Pvt. Ltd., New Delhi (1973).

Katyal, J.C. and B.D. Sharma: A new technique of plant analysis to resolve iron chlorosis. Plant Soil, 55, 105-119(1980).

Lindsay, W.L. and W.A. Norvell: Development of a DTPA soil test for zinc, iron, manganese and copper. Soil Sci. Soc. Am. J., 42, 421-428 (1978)

Olson, R.V. and C.W. Carlson: Iron chlorosis of sorghum and trees as related to extractable soil iron and manganese. Proc. Soil Sci. Soc. Am., 14, 109-112 (1950).

Pal, S., S.P. Datta, R.K. Rattan and A.K. Singh: Diagnosis and amelioration of iron deficiency under aerobic rice. J. Plant Nutr., 31, 919-940 (2008).

Sarkar, A.K.: Soil acidity and liming. In: Soil Science; An Introduction (Eds.: R.K. Rattan, J.C. Katyal, B.S. Dwivedi, A.K. Sarkar, T. Bhattacharyya, J.C. Tarafdar and S.S. Kukal). Indian Society of Soil Science, New Delhi, pp. 329-352 (2015).

Sarkar, R., B. Basavaraj and S. Kar: Iron and calcium availability to groundnut plants as affected by calcium carbonate and water levels in calcareous soil. J. Crop Improv., 21, 209-220 (2008).
Sasaki, Y., Y. Hosen, S. Peng, L. Nie, R. Rodriguez, R. Agbisit, L. Fernandez and B.A.M. Bouman: Do abiotic factors cause a gradual yield decline under continuous aerobic rice cultivation? A pot experiment with affected field soils. Soil Sci. Plant Nutr., 56, 476482 (2010).

Shoemaker, H.E., E.O. McLean and P.F. Pratt: Buffer method for determining lime requirement of soils with appreciable amount of extractable aluminium. Proc. Soil Sci. Soc. Am., 25, 274-277 (1961).

Sidhu, G.S. and B.D. Sharma: Diethylene triamine penta acetic acidextractable micronutrients status in soil under a rice-wheat system and their relationship with soil properties in different agroclimatic zones of Indo-Gangetic plains of India. Comm. Soil Sci. Plant Analy., 41, 29-51(2010).

Takkar, P.N. and N.P. Kaur: $\mathrm{HCl}$ method for $\mathrm{Fe}^{2+}$ estimation to resolve iron chlorosis in plants. J. Plant Nutr., 7, 81-90 (1984).

WHO: Iron deficiency anaemia. http://www.who.int/nutrition/topics/ ida/en/. Accessed 21 February 2016 (2016).

Zeng, W.A., F. Li, H. Zhou, X-Li Qin, Z.J. Zou, T. Tian, M. Zeng and B.H. Liao: Effect of calcium carbonate on cadmium and nutrients uptake in tobacco (Nicotiana tabacum L.) planted on in contaminated soil. J. Environ. Biol., 37, 163-168 (2016).

Zhang, J., M.Y. Wang and L.H. Wu: Can foliar iron-containing solutions be a potential strategy to enrich iron concentration of rice grains (Oryza sativa L.)? Acta Agric. Scand. Sect. B Soil Plant Sci., 59, 389-394 (2009).

Zou, C., X. Gao, R. Shi, X. Fan and F. Zhang: Micronutrient deficiencies in crop production in China. In: Micronutrient Deficiencies in Global Crop Production (Eds.: B.J. Alloway). Springer, Verlag, pp 127-148(2007). 